\title{
Correction to: Screening and computational analysis of colorectal associated non- synonymous polymorphism in CTNNB1 gene in Pakistani population
}

\author{
S. Razak ${ }^{1,2^{*}}$, N. Bibi ${ }^{3}$, J. A. Dar ${ }^{4}$, T. Afsar ${ }^{1}$, A. Almajwal ${ }^{1}$, Z. Parveen ${ }^{5}$ and S. Jahan ${ }^{2}$
}

\section{Correction to: BMC Medical Genetics (2019) 20:171 https://doi.org/10.1186/s12881-019-0911-y}

Following publication of the original article [1], the authors have flagged that the article has published with an error in the order of the affiliations.

Namely, in the affiliations list (under the 'Author details') affiliations ' 1 ' and ' 2 ' are interchanged; affiliation ' 1 ' should be ' 2 ', and vice-versa.

Please find the corrected order of affiliations in this correction.

\section{Author details}

'Department of Community Health Sciences, College of Applied Medical Sciences, King Saud University, Riyadh, Saudi Arabia. ${ }^{2}$ Reproductive physiology lab, Department of Animal Sciences Quaid-i-Azam University, Islamabad, Pakistan. ${ }^{3}$ Department of Bioinformatics, Shaheed Benazir Bhutto Women University, Peshawar, Khyber Pakhtunkhwa, Pakistan. ${ }^{4}$ Department of Zoology, College of Science, King Saud University, Riyadh, Saudi Arabia. ${ }^{5}$ Faculty of Biological Sciences Quaid-I-Azam University Islamabad and University of Iceland, 101 Reykjavik, Iceland.

Published online: 24 February 2020

\section{Reference}

1. Razak S, et al. Screening and computational analysis of colorectal associated non-synonymous polymorphism in CTNNB1 gene in Pakistani population. BMC Med Genet. 2019;20:171. https://doi.org/10.1186/s12881-019-0911-y.

*Correspondence: ruhail12345@yahoo.com; smarazi@ksu.edu.sa

'Department of Community Health Sciences, College of Applied Medical Sciences, King Saud University, Riyadh, Saudi Arabia

${ }^{2}$ Reproductive physiology lab, Department of Animal Sciences Quaid-i-Azam University, Islamabad, Pakistan

Full list of author information is available at the end of the article

(c) The Author(s). 2020 Open Access This article is distributed under the terms of the Creative Commons Attribution 4.0 International License (http://creativecommons.org/licenses/by/4.0/), which permits unrestricted use, distribution, and reproduction in any medium, provided you give appropriate credit to the original author(s) and the source, provide a link to the Creative Commons license, and indicate if changes were made. The Creative Commons Public Domain Dedication waiver (http://creativecommons.org/publicdomain/zero/1.0/) applies to the data made available in this article, unless otherwise stated. 